\title{
Mega-regionalism in Asia Pacific
}

Exposición realizada por el Profesor Christopher Findlay, Vicepresidente del Comité Australiano de Cooperación Económica en el Pacífico y Decano de Profesiones de la Universidad de Adelaida, 11 de abril de 2013. Desayuno anual de la Fundación Chilena del Pacífico

Thank you for this opportunity to discuss some important developments in our region, in particular, the emergence of what might be called mega-regionalism.

Let me explain what I mean by that phrase, identify the origins of the phenomenon and discuss a few aspects of its implications, as well as talk about how the mega-regionalism game might play out.

\section{What Is Mega Regionalism?}

By mega-regionalism I mean not only the new multi-country trade agreements in the Asia Pacific but also the extent of interaction between them.

We have had some multi country agreements (rather than having just two countries involved as in a bilateral) for some time, like that around ASEAN and another around North America.

But the change has been new structures like the TPP, now with 11 members across the Pacific, and the Regional Comprehensive Economic Partnership of RCEP which is the ASEAN +6 group in East Asia and includes NEAsia, Australia, NZ and India.

So compared to others, these newer agreements have a wider geographic coverage, and membership is not limited to economies which are next to each other. 
This audience is more likely to be familiar with TPP, of which Chile was a founding member, and less so about RCEP, so perhaps today that is one point of interest.

\section{Why Has Mega Regionalism Grown}

Where did the interest in these newer multi country structures come from? Factors include

- The economics of larger membership - trade agreements with bigger membership generate much greater gains for each participant. This does depend on the size of the trade barriers being reduced, the complementarities among economies in the group and their size but there is a positive link to larger membership.

- The growth in interest in the concept of supply chains, based on the fragmentation of production, and wanting to have a policy environment that supports their growth across a group of countries (bilateral agreements are not enough - they maybe inconsistent and offer insufficient coverage)

- The growth of bilateral agreements itself has added, it is argued, to complexity and to costs of doing business which we have sought to ameliorate by wider membership agreements.

There is also an interest in making greater progress on new issues, like regulation and competition and SOEs, as traditional trade barriers - while significant in some areas - decline overall.

Also there is some experience that dealing bilaterally is very hard (look at Australia's efforts in NEAsia) so having more countries with more change going on creates more scope to reach a deal that can be sold to domestic political interests. At least, that might be the hope.

Some of these points beg the question of why not, if bigger membership is better, go to the WTO, which has global membership. The WTO has a vital contribution in this context of mega-regionalism - more on that shortly - but proponents of these new structures would probably say that more members 
are better, yes, but there are diminishing returns since negotiating costs start to rise in a larger group.

Are These Some Specific Events That Triggered Recent Development?

The increasing membership of the TPP is one of these events. The US decision in 2010 to become even more active in TPP was critical.

According to the communication from the USTR to Congress, its motivations include access to rapidly growing Asian markets, the prospect of exports and jobs including for US hi tech firms and SMEs, and also treatment of issues that were of concern to Congress such as labour rights and environmental standards.

But also, as we'll see in a moment, there had been consideration of East Asian based agreements since 2003 for ASEAN+3 and 2006 from ASEAN+6 and participation in the TPP made sense in part as insurance in that context for the US too.

However, this decision by the US led to a reaction in East Asia, perhaps making US expectations, of the creation of a trade agreement from which it was excluded, actually come true - this sort of interactivity is a feature of the era of megaregionalism.

The recent big addition to TPP has been Japan which confirmed its interest in March this year. The other members now have to accept it. ${ }^{1}$ Then in May there is the 17 th round of negotiations in Lima.

Japan had been agonizing for years about the joining the TPP. Proponents argued it would support the reform agenda in Japan, including in agriculture. This was much resisted, including in public demonstrations.

The tension with China around the Senkaku Islands issue, then provided greater scope for the Japanese Prime Minister to argue for a clear commitment to an arrangement in which the US was playing a lead role and thereby demonstrate a commitment to the relationship with the US.

If so, here is an example of what is another key feature of the era of mega-regionalism, that is, the interplay of strategic

This was done at the APEC Trade Ministers meeting in Surabaya on 21 April 2013. 
or security issues with the evolution of the architecture of these international economic regimes.

Also of assistance to the break the domestic bottleneck in Japan was support from the US and what has been called the 'summit wave' in which following a meeting of the Japanese PM and the US President in February they said

"The two governments confirm that should Japan participate in the TPP negotiations, all goods would be subject to negotiation,» Obama and Abe said in a joint statement, adding, "As the final outcome will be determined during the negotiations, (Japan) is not required to make a prior commitment to unilaterally eliminate all tariffs upon joining the TPP (discussions).»²

In fact, the second part of this statement was obvious, and nothing new, but it did give the Japanese PM a message to take home.

As I understand it, the debate in Japan around the TPP will shift to what exclusions might be sought, rather than whether or not to be in the arrangement. Whether this shift suits other members of the TPP, given their apparent level of ambition, is still a question.

The development of RCEP itself might have been part of the story, more on that in a moment.

In any case, the extent of activity in TPP, the sense that the process was getting serious, the growth in the size of the meetings and the number of them already completed, plus the joining of Japan, all adds to the perspective that TPP is 'going somewhere'.

\section{What About The Interaction With Rcep?}

This is part of the story, but what about RCEP - where did it come from?

ASEAN and its dialogue partners had been discussing for some time a wider arrangement in East Asia, partly prompted

2 More detail at http://www.japantimes.co.jp/news/2013/02/23/nationallabe-obama-talks-set-stage-for-tpp-entry 
by the experience of the Asian Financial Crisis, a desire to be more self reliant and a perception (misleading actually) that regional trade was becoming more concentrated - it was so in components, but not final products where in fact export shares to the region were falling, not rising.

There are had been parallel tracks, ASEAN+3 favoured by China in particular and ASEAN+6, favoured by at least some parts of the Japanese bureaucracy, perhaps to provide a larger group in which to manage its relationship with China.

By 2009, working groups had been set up to work on specific topics related to these arrangements. But ASEAN with the split sponsorship was stuck, which should it support?

These activities continued on parallel tracks for some time then the matter was resolved when in August 2011 China and Japan made a joint proposal for a regional FTA, which was incorporated into a concept that ASEAN leaders had already been developing.

A key driver of the coming together of China and Japan on this proposal, essentially founded in China's willingness to push less strongly for ASEAN+3, was a result of progress in the TPP, as just described, which was also captured in a statement of ambition made at the APEC leaders meeting in 2011.

So TPP itself prompted a resolution around plans for arrangements in East Asia.

How To Compare Rcep And Tpp?

There are some significant differences in the two arrangements.

One is the membership structure: RCEP apparently has ASEAN at the Centre, and with China in and the US out, and TPP having a US focus.

But they also have different philosophies - or what is more often called the 'level of ambition'.

RCEP takes an ASEAN approach of allowing for different pathways for different economies and allowing for differential treatment. This is designed to accommodate the perception that adjusting to globalization is costly, and although the benefits are huge, the confidence to proceed demands an ability to quarantine some areas as well as time to adjust and to build capacity to compete and manage a more open economy. 
RCEP most likely will build up from the bottom, on the set of agreements which ASEAN already has with each one of the +6 countries. However, these vary mightily and there is a lot of work to do to join them together. On the other hand, this is a less risky approach than trying to write a new agreement which, with the philosophy just outlined would most likely lead to 'just another agreement', rather than making progress to integration.

The RCEP philosophy would also make it possible, I think, for the members to sign up to something relatively soon even though the TPP team might say it is 'soft'. But that possibility is also putting pressure on the TPP to meet its deadlines and to conclude. Indeed, reports are that the US is keen to sign an agreement this year.

TPP has the expectation of a standard approach for all economies to sign on to, across a wider range of areas. There might be some variation in schedules, but everyone will be expected to get to the same end point. It would be one agreement, not a bundle of agreements.

There are however challenges in the TPP process, given the various sensitive sectors of the key players.

- Agriculture remains a theme of those sectors, an area of mutual interest to Chile and Australia.

- Textiles and clothing is a sensitive area in developed economies

There is debate about the economics of the IP protection position of the $\mathrm{US}^{3}$ and about the provision of investor-state dispute settlement.

Some economies are asking questions such as - is it worth the effort on the new issues if we don't get the market access that we seek?

Furthermore, the TPP does not align with current supply chains, though its proponents may argue new chains may follow its construction. ${ }^{4}$

3 http://www.eastasiaforum.org/2013/03/31/intellectual-propertyand-wealth-transfers-in-the-trans-pacific-partnership/

4 http://www.eastasiaforum.org/2013/01/06/will-the-tpp-facilitateor-disrupt-supply-chains/ 
But if there does emerge a rush to complete the TPP, perhaps because RCEP looks like it is able to do so, this might also lead to some compromise on the original ambitions. Observers are reporting some signals in this respect.

\section{SCENARIOS}

So how might his play out.

The agreements could continue on separate paths but the number of mutual members might rise, as on the one hand if access to Asian markets is a drawcard for RCEP and on the other hand if the TPP style is regarded as useful to support domestic reform as well as contribute to integration.

The two options might even be regarded by some as complementary, and choices of which to join made by economies at different stages of development.

But the prize remains convergence, convergence to an arrangement in which both China and the US participate. The Petri/Plummer modeling results point to very big numbers for the gain if this is achieved.

And anxiety would remain without that - while the world's two great powers are in separate trade and investment agreements.

So convergence is becoming the talking point. Will it and can it be done?

Our colleague Jusuf Wanandi has written

'both the Trans Pacific Partnership (TPP) and Regional Comprehensive Economic Partnership (RCEP) can be complementary, if the US is willing to lower the TPP threshold, while the RCEP should raise its threshold to become more meaningful for the region to participate. Only then the most maximum results can be achieved for the benefit of the region.'

This is a very interesting idea but it is a challenge to think about how to make convergence to avoid the resulting agreement becoming just another compromised trade agreement, admittedly one with a lot of members, sitting in the bowl of noodles that already exists.

5 http://www.accessmylibrary.com/article-1G1-324560954/insightchina-peaceful-rise.html 


\section{Policy IMPLICATIONS}

My response to that challenge would be to say let's have the conversation about convergence and what it might look like. But this conversation has many dimensions, it has to carefully designed and I suggest the following aspects are critical.

First, the conversation has to take place outside the agreements themselves, because everyone should be involved, current members and non members (that is potential members). Indeed some analysts have argued for a 'third track', in which China and the US continue to rehearse their common interests. I think we have that. APEC and its related networks is a good place to do that. Some clarity about the purpose of all is also important constant reference to what we are trying to achieve and why it matters to business will help.

Speaking of APEC, it has another contribution in delivery of capacity building, which can help narrow the philosophical gap between RCEP and TPP.

Second, it will be important to refer to implications for the WTO and to how to transfer commitments here in the converged structure to there in the WTO. This is because of the importance of trade links with the rest of the world for East Asia in particular, as I have mentioned. Some commentators have called for a resolution of the tensions and uncertainties I have been speaking about by the multilateralisation of any outcomes in both agreements as they occur, which is an important and interesting idea. ${ }^{6}$

And then third the terms of accession also matter - it is important in order to achieve convergence that the clubs remain open, and that new members are not unduly discriminated against in their entry conditions. There is a risk of that action by the founding members.

So to conclude, in this changing environment which I have tried to characterize the old institutions like APEC and the WTO really do still matter, and indeed they now may matter even more.

http://www.eastasiaforum.org/2013/01/06/how-to-multilateraliseasian-regionalism/ 